\title{
Customer Satisfaction and Word of Mouth Customers of Islamic Banks in Central Sulawesi Province, Indonesia
}

Dwi Wahyono ${ }^{1,2 *}$, Syamsul Bachri ${ }^{2}$, Maskuri Sutomo ${ }^{2}$, Husnah $^{2}$

${ }^{1}$ Panca Bhakti School of Economics of Palu, Central Sulawesi, Indonesia

${ }^{2}$ Faculty of Economics, Tadulako University, Central Sulawesi, Indonesia

DOI: $10.36348 /$ sjef.2020.v04i05.004

| Received: 18.05 .2020 | Accepted: 26.05.2020 | Published: 28.05.2020

*Corresponding author: Dwi Wahyono

\section{Abstract}

The purpose of the study was to analyze the effect of satisfaction on word of mouth customers of Islamic banks in Central Sulawesi Province. This study applied two survey methods, i.e., descriptive survey and explanatory survey and was conducted from January to May - July 2018. Samples were Islamic bank customers in Central Sulawesi Province. The sample size of the study was 345 respondents spreading in several Islamic banks in Central Sulawesi Province, which included: Syariah Mandiri KC Palu Bank, Syariah Mandiri KC Luwuk Bank, BNI Syariah Bank, Muamalat Bank, BRI Syariah Bank. The variables of the study were customer satisfaction and word of mouth. The results of the study showed that customer satisfaction was classified as a good category, with the mean score was 3.62. The mean value for WOM intention was 3.55 (good category), positive valence WOM value was 3.61 (good category), negative valence WOM value was 3.59 (good category), WOM content value was 3,77 (good category). The satisfaction had a significant effect on the word of mouth Islamic bank customers in Central Sulawesi with a p-value $=0.036(p<0.05)$. It can be concluded that if satisfaction increases, the desire of Islamic bank customers in Central Sulawesi to do WOM would also increase.

Keywords: Satisfaction, Word of mouth customer, Islamic banks.

Copyright @ 2020: This is an open-access article distributed under the terms of the Creative Commons Attribution license which permits unrestricted use, distribution, and reproduction in any medium for non-commercial use (NonCommercial, or CC-BY-NC) provided the original author and source are credited.

\section{INTRODUCTION}

Over time, business competition occurs between companies is getting tougher. Each company is trying to win the competition. In carrying out the company's activities every day the company continues to compete to be the best, to be a company where investing with low risk is in the eyes of investors, being the best place to work in the eyes of the workforce, and able to produce the best products and services in the eyes of consumers. For this reason, every company is required to always understand and comprehend what is happening in the market and what consumers desire [1].

Consumers tend to seek additional information from outside formal information sources so that customers will be directly involved with word of mouth. Word of mouth (WOM) is known as a face to face communication about brands, products, or services among people who know or feel that they are not related to any commercial entities [2]. Word of mouth is the dominant force in the market for services [3]. The advantage key of word of mouth compared to the classical mass-marketing is an enticement and a mandate of individual customers.

Word of mouth behavior can be linked to customer satisfaction and dissatisfaction with previous consumption experience. Satisfied customers will be the spokesperson for your product more effectively and convincingly than other types of advertising [4]. The results of research on satisfaction have a positive and significant effect on word of mouth, the higher level of satisfaction of a customer, the greater the chances of these customers to do word of mouth [5]. Thus, every company becomes very important to provide the best for customers to be satisfied. Satisfaction alone is not a guarantee that customers will do word of mouth. However, by offering incentives would increase the likelihood of them doing word of mouth [6]. While other studies have shown that satisfaction may affect in performing word of mouth through loyalty, so only satisfied and loyal customers would perform word of mouth. The purpose of this study was to analyze the effect of satisfaction on word of mouth Islamic bank customers in Central Sulawesi Province. 


\section{METHOD}

The study applied two survey methods, i.e., descriptive survey and explanatory survey. This study was conducted from January to May - July 2018 and located in all Islamic banks of Central Sulawesi Province.

The sample chosen in this study was a sample taken from the population whose characteristics were studied, namely customers of Islamic banks located in Central Sulawesi Province. The sample size of the study was 345 respondents spread in several Islamic banks in Central Sulawesi Province, which included: Syariah Mandiri KC Palu Bank, Mandiri Syariah KC Luwuk Bank, BNI Syariah Bank, Muamalat Bank, and BRI Syariah Bank.

\section{Variables}

Customer satisfaction was measured using four statements relating to security systems, services, systems that apply in Islamic banks, and those associated with the management of Islamic banks. Word of mouth was measured using four dimensions consisting of WOM Intensity, Positive Valence WOM, Negative Valence WOM, and WOM content. Furthermore, the dimensions were expanded into several indicators, which were then derived into statement forms.

\section{RESULT AND DISCUSSION}

Table 1 shows that the number of male customers at Islamic banks in Central Sulawesi Province was 125 respondents or about $36.23 \%$. The number of female customers was 220 respondents or approximately $63.77 \%$. Most respondents were between 36-40 years old, about 101 respondents (29.27\%). The second was between 41-45 years old about 98 respondents $(28.40 \%)$. The third was 31 - 35 years old, as many as 45 respondents $(13.04 \%)$. Respondents aged between 26-30 years were 40 respondents (11.59\%). Then, respondents aged $>46$ years were 39 respondents $(11.30 \%)$ and the smallest number of respondents were aged $<25$ years as many as 22 respondents or about $6.38 \%$. Based on education, Respondents was dominated by bachelor's degrees as many as 162 respondents or approximately $46.96 \%$, then followed by a graduate degree as many as 94 respondents or approximately $27.89 \%$ then those with high school education were 46 respondents or about $13.3 \%$. As regards to occupation, the highest number dominated by employees, around 128 respondents or about $37 \%$, followed by civil servants about 122 respondents (35\%). Afterward, Muslim customers were the highest number of respondents, approximately 297 respondents or about $86.1 \%$, and then Christians as many as 31 respondents or about $8.99 \%$.

Table-1: Characteristic of Respondent

\begin{tabular}{|c|c|c|}
\hline Characteristics & n (325) & $\%$ \\
\hline \multicolumn{3}{|l|}{ Sex } \\
\hline Male & 125 & 36.23 \\
\hline Female & 220 & 63.77 \\
\hline \multicolumn{3}{|l|}{ Age (years) } \\
\hline$<25$ & 22 & 6.38 \\
\hline $26-30$ & 40 & 11.59 \\
\hline $31-35$ & 45 & 13.04 \\
\hline $36-40$ & 101 & 29.27 \\
\hline $41-45$ & 98 & 28.40 \\
\hline$>46$ tahun & 39 & 11.30 \\
\hline \multicolumn{3}{|l|}{ Education } \\
\hline Middle School & 3 & 0.87 \\
\hline High School & 46 & 13.30 \\
\hline Diploma & 30 & 8.69 \\
\hline Undergraduate & 162 & 46.96 \\
\hline Graduate & 94 & 27.25 \\
\hline Post-Graduate & 10 & 2.89 \\
\hline \multicolumn{3}{|l|}{ Occupation } \\
\hline Employees & 128 & 37.00 \\
\hline Entrepreneurs & 60 & 17.00 \\
\hline Civil servants & 122 & 35.00 \\
\hline College student & 34 & 9.86 \\
\hline \multicolumn{3}{|l|}{ Religion } \\
\hline Muslim & 297 & 86.10 \\
\hline Christian & 31 & 8.99 \\
\hline Catholic & 4 & 1.16 \\
\hline Buddha & 6 & 1.74 \\
\hline Hindu & 7 & 2.03 \\
\hline
\end{tabular}

Table 2 shows that 259 respondents or about $75.07 \%$ had savings in other banks, while the remaining 86 respondents or approximately $24.94 \%$ were not being customers in different banks. The number of respondents was dominated with a period of saving between 1-2 years, was 88 respondents or about $25.51 \%$, then respondents who had a term less than one year were 71 respondents or approximately $20.57 \%$. The biggest reason of respondents being customers at Islamic banks because of the promotion of the company, was 128 respondents or about $37.1 \%$ while due to the suggestions from friends/family was 115 respondents or approximately $33.33 \%$ and the remaining 102 respondents or about $29.6 \%$ was due to their own will. The purposed of respondents to be customers in Islamic banks is to avoid the usury, was 216 respondents or about $62.61 \%$. 
Table-2: Account Ownership in Other Banks, Duration of Being a Customer, Reasons being the Customer and the Objective of becoming a Customer in Islamic Bank

\begin{tabular}{|c|c|c|}
\hline \\
\hline Variable & n (325) & $\%$ \\
\hline \multicolumn{3}{|c|}{ Account Ownership in Other Banks } \\
\hline Yes & 259 & 75.07 \\
\hline No & 86 & 24.92 \\
\hline \multicolumn{3}{|l|}{ Duration of Being a Customer } \\
\hline$<1$ years & 71 & 20.57 \\
\hline $1-2$ years & 88 & 25.51 \\
\hline $2-3$ years & 65 & 18.84 \\
\hline $3-4$ years & 63 & 18.26 \\
\hline$>5$ years & 58 & 16.12 \\
\hline \multicolumn{3}{|l|}{ Reasons being the Customer } \\
\hline Own will & 102 & 29.60 \\
\hline Advice from friends/family & 115 & 33.33 \\
\hline Company promotion & 128 & 37.10 \\
\hline \multicolumn{3}{|c|}{ The Objective of becoming a Customer } \\
\hline Profit-sharing system & 129 & 37.39 \\
\hline Avoiding usury & 216 & 62.61 \\
\hline
\end{tabular}

Table 3 shows that the fourth statement was related to customer satisfaction was the biggest contribution with a mean value of 3.62 which was categorized as a good category, namely, respondents who answered as strongly agreeing was $21.45 \%$, who answered as agree was $56.52 \%$, who answered as quite agree was $20 \%$, who answered as disagree was $1.74 \%$, and those who answered strongly disagree was $0.29 \%$.
In accordance with the facts in the field where the bank employee has reminded the customer three days before the installment payment, thus the customers concerned could prepare themselves early so that if there are busy customers, it will be helped because it has been reminded. Likewise, the completeness of the employee file also always reminded to complete if there's some missing.

Table-3: Customer satisfaction at Islamic Banks in Central Sulawesi Province

\begin{tabular}{|c|c|c|c|c|c|c|c|c|c|c|c|c|}
\hline \multirow{3}{*}{ No } & \multirow{3}{*}{ Items } & \multicolumn{10}{|c|}{ Responses } & \multirow[t]{3}{*}{ Mean } \\
\hline & & \multicolumn{2}{|c|}{$\begin{array}{c}\text { Strongly } \\
\text { agree }\end{array}$} & \multicolumn{2}{|c|}{ Agree } & \multicolumn{2}{|c|}{$\begin{array}{l}\text { Quite } \\
\text { agree }\end{array}$} & \multicolumn{2}{|c|}{ Disagree } & \multicolumn{2}{|c|}{$\begin{array}{c}\text { Strongly } \\
\text { disagree }\end{array}$} & \\
\hline & & $\mathrm{N}$ & $\%$ & $\mathrm{~N}$ & $\%$ & $\mathrm{~N}$ & $\%$ & $\mathrm{~N}$ & $\%$ & $\mathrm{~N}$ & $\%$ & \\
\hline 1 & Satisfied with security & 73 & 21.2 & 169 & 48.9 & 101 & 29.2 & 2 & 0.5 & 0 & 0.0 & 3.91 \\
\hline 2 & Satisfied with the service & 44 & 12.7 & 187 & 54.2 & 95 & 27.54 & 16 & 4.6 & 3 & 0.8 & 3.73 \\
\hline 3 & Satisfied with the applicable system & 17 & 4.9 & 136 & 39.4 & 118 & 34.2 & 60 & 17.3 & 14 & 4.0 & 3.24 \\
\hline 4 & Satisfied with management & 74 & 21.4 & 195 & 56.5 & 69 & 20.0 & 6 & 1.7 & 1 & 0.2 & 3.97 \\
\hline \multicolumn{12}{|c|}{ The mean value of customer satisfaction } & 3.62 \\
\hline
\end{tabular}

According to the results of interviews with respondents, the Islamic bank system is not entirely free from usury; for example, Islamic banks still use shared ATMs, which should use Islamic ATMs so that they are not mixed with conventional ones due to the different application system. Then in the determination of the profit-sharing system, if the application system is profit sharing, the loan installments should be different each month because the profit sharing will be different. Still, monthly installments remain the same, so that no differences to the Bank interest. Variable of customer satisfaction with a mean value of 3.62 was categorized as a good category, which means that even though there are still many weaknesses in Islamic banks, but there are still many advantages of Islamic banks, so customer satisfaction met the satisfied category.

Table 4 shows that the mean value for WOM intention with a mean value of 3.35 , categorized as a good category. Based on the results of interviews, there is a tendency for new customers will talk about sharia products to others, because this is a new experience so that there is something different from the usual, then it becomes a passion for talking to others. But some customers do not have the desire to tell others unless asked for an opinion.

For the WOM intention dimension, the largest contribution to the first statement relating to the frequency of communication about Islamic banks, where the answer is very agree was $13.91 \%$, who answered agree was $42.61 \%$, who answered quite agree was $34.20 \%$, who answered disagree was $9.28 \%$ and who answered strongly disagree was $1.46 \%$. With a mean value of 3.61 , meaning in the good category. This is due to the system that is treated by Islamic banks is more attractive than conventional Banks where Islamic banks do not know the name of Bank interest, but rather applies to the profit-sharing system.

Results of interviews shown a frequency arising from communication is divided into two, namely the frequency that arises with planned by the customer and the frequency that is not planned by the customer. In the 
planned context, the customer intentionally discloses the Islamic bank to social partners either through Facebook, Twitter or through Whatsapp. Whereas the unplanned one is where the customer talks unplanned, but is natural and spatial, and usually often occurs when a gathering is inherited, restaurants and offices.

Based on the analysis, commonly, customers often talk about Islamic banks to others. This is due to positive things and there are improvements made by the management to make customers comfortable. For the Positive valence WOM dimension, the largest contribution of the first statement related to recommending Islamic bank products to others where those who answered strongly agree was $20.29 \%$, who answered agree was $50.72 \%$, who answered quite agree was $22.61 \%$, who answered disagree was $5.80 \%$ and those who answered strongly disagree was $0.58 \%$ with a mean value of 3.84 categorized as a good category.

Recommending to other parties is one of the strategies implemented by Islamic banks in the Central Sulawesi Province. Every customer who uses Islamic bank products is given maximum service in the hope that customers will feel satisfied, tell others and then recommend it. The employees who are processing files of a customer sometimes also suggest to the relevant customer if there are office friends, family, or anyone interested may be notified. Thus, it is expected that each consumer will also recommend to others. But some respondents were about $0.58 \%$ do not recommend to others, because they feel the service is less satisfactory. Some do not want to recommend it because they are afraid that later it does not match the expectations of those recommended, so they prefer to remain silent.

Table-4: Distribution of Word of Mouth Frequency at Islamic Banks in Central Sulawesi Province

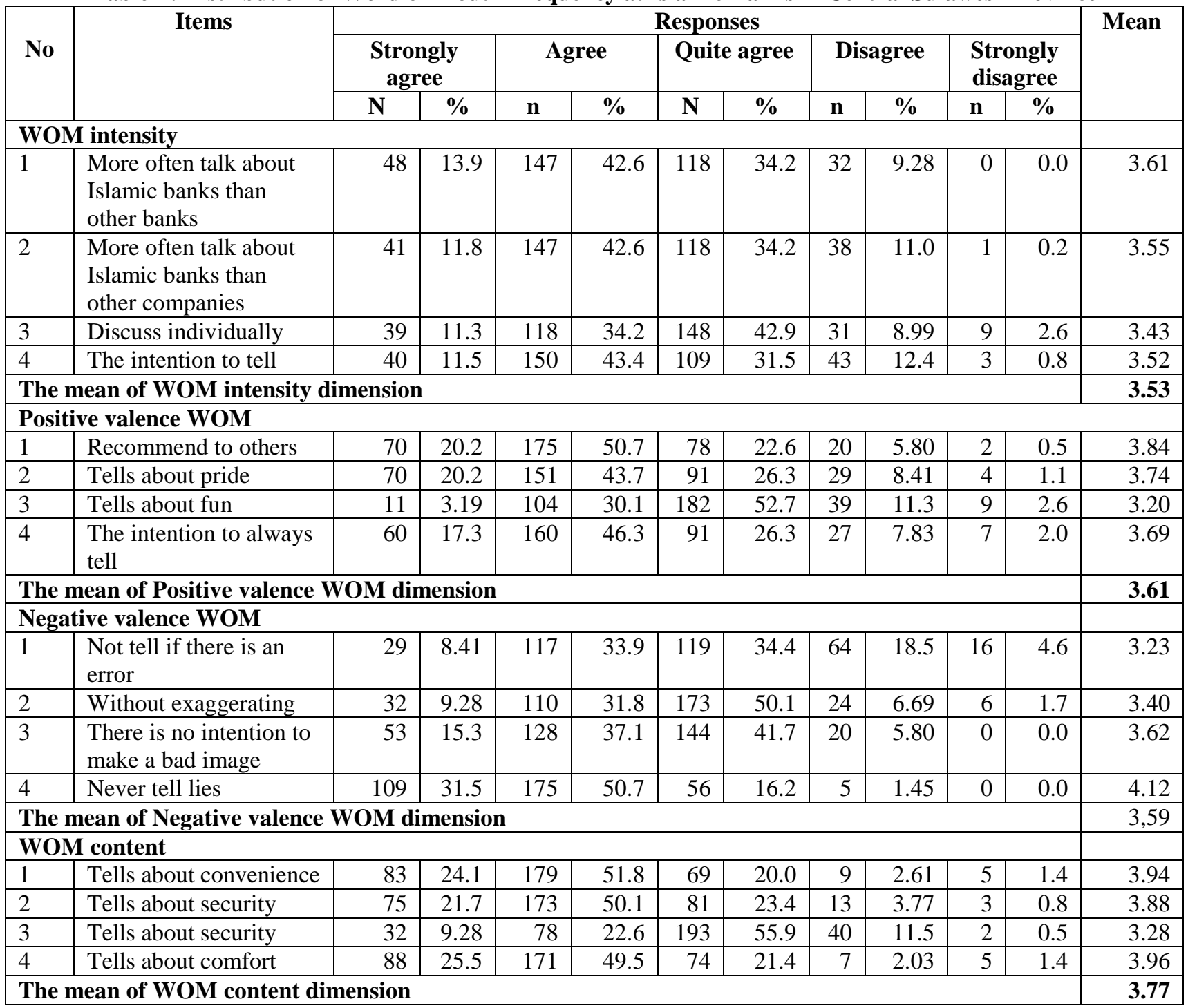

For the Negative valence WOM dimension, the most significant contribution to the first statement relating to the unwillingness of a customer to say negative things about Islamic banks which the answer was about $8.71 \%$, who answered agree was about $33.91 \%$, who responded quite agree was approximately 
$34.49 \%$, who answered disagree was about $18.55 \%$. Those who reacted strongly disagree was about $4.64 \%$. The mean of Negative valence WOM dimension was 3.23 and categorized as quite a good category.

Based on the results of interviews with respondents that in general, they will not convey things that are not true about Islamic banks, because when doing so there is no benefit to be gained, even if done it will cause problems. But mostly if a customer feels disappointed by the Islamic bank, then they will tell others, this is caused as a form of venting disappointment towards the bank and as an effort to prevent others from experiencing the same thing. But there were $8.41 \%$, although feeling disappointed, they will not tell others because it is considered as spreading the badness of others, so they prefer silence, but then they will withdraw quietly.

Table-5: Correlation of Customer Satisfaction with Word of Mouth

\begin{tabular}{|l|c|c|c|c|}
\hline & $\begin{array}{c}\text { Regression } \\
\text { Weight }\end{array}$ & $\begin{array}{c}\text { Critical } \\
\text { Ratio }\end{array}$ & $\begin{array}{c}\text { Probability } \\
(\mathbf{p})\end{array}$ & Explanation \\
\hline Customer satisfaction $\rightarrow$ Word of Mouth & 0.243 & 2.100 & .036 & Significant \\
\hline
\end{tabular}

The estimation parameters in table 5 show that between the variables of customer satisfaction with word of mouth has a significant result because the probability value is below the significance level of $5 \%$ or 0.05 , which is 0.036 with a CR value of more than 2.00 that is 4.100 . The estimated value between the variable of customer satisfaction with word of mouth is equal to 0.243 , which means that if customer satisfaction has increased, then word of mouth will also increase. From the results of statistical tests, the probability value is below the significance level of $5 \%$ or 0.05 , which is 0.036 . Therefore, satisfaction has a significant effect on the shredding of Islamic bank customers in Central Sulawesi.

From the results of hypothesis testing, it was found that satisfaction has a positive and significant effect on word of mouth. It means that if satisfaction increases, then the desire of Islamic bank customers in Central Sulawesi to do Word of Mouth will also increase. So that customers are interested in use or consume services provided by companies. The role of word of mouth is considered very important because before consuming, information from other people who have experienced it before and information from experts based on their knowledge becomes information that is often relied upon. To make word of mouth run as desired, we need stimulus or stimulation that can affect the recipient of information. The product or service quality, customer value, and price are topics that are often discussed in WOM. If customers are satisfied with the service, they will be willing to do positive WOM. Customers will be more active in doing positive WOM if there are triggers and conditions [7].

Positive word of mouth is a characteristic of loyal customers and very profitable companies. The phenomenon of word of mouth is believed to encourage consumer purchases, affect the community more efficiently because it does not spend a large budget, may enhance a positive image, and be able to touch the emotional customers because it is influenced by satisfaction. Customers want to do word of mouth to others because they feel that the products or services consumed provide satisfaction. Customers are satisfied because the accuracy and customers feel the quality the same as expected [8].

Satisfied customers will generally remain loyal for a long time, repeat buying when the company releases a new product and renew an old product, talk positively about the company's products or services to others, and satisfied customers tend to recommend to others [9]. Rusadi dan Sujito [10]. Determine the results of the study, an indirect effect between product quality and word of mouth through satisfaction [10].

Service quality is crucial for service companies so that it cannot be ruled out, because it may enhance competitive advantage to maintain customer satisfaction. The company hopes that customer satisfaction will help to create effective communication. Up to a certain, word of mouth has a very strong correlation with satisfaction. Customer satisfaction provides many benefits, one of which allows for recommendations by word of mouth (WOM) which would be beneficial for the company in the long term, so that the future will be more and more people are buying goods or services that companies sell [11]. Customer satisfaction is important for service providers because customers will disseminate their satisfaction to prospective customers, thus increasing the company's reputation. So if the customer is being satisfied, then he will create WOM to colleagues and family. When a marketer can offer the maximum level of satisfaction to consumers, consumers will tend to do positive word of mouth [12]. Besides, the person will also state that there is a positive influence between customer satisfaction and word of mouth. When customers are satisfied, positive WOM will be created and they are more likely to give purchase recommendations to others [13].

Satisfaction significantly influences WOM and the desire to make a purchase recommendation. When consumers are satisfied, they will give positive WOM and recommend others [6]. While customers are not satisfied, they will forbid others to make purchases. Customer satisfaction may affect performance results, including loyalty and communication from WOM or referring interest. Therefore, customer satisfaction 
encourages the creation of WOM communication [14]. Babin et al. [15] stated that customer satisfaction has a positive effect on WOM's interest [15]. Customer satisfaction is positively related to WOM [12]. Customer satisfaction is influenced by product quality, and then satisfaction will have a positive impact on word of mouth [10].

During this time, Islamic banks in Central Sulawesi have tried to provide satisfaction to their customers, particularly on security issues, Islamic banks maintain confidentiality, it is not permitted for an employee to provide information related to customer biodata to anyone. Likewise related to the issue of security of funds held by customers is also a concern of the bank by creating a system that is truly safe for customers.

Service aspects of Islamic banks already have excellent service standards that must be carried out by all employees such as, always smile to the customers, initiating communication with greetings and so on. Customer satisfaction to the security system and services provided by Islamic banks will certainly be a positive value because it has a pleasant experience, and everyone will be happy to share experiences let alone the experience is very memorable, thus the more secure and more satisfied with the service the stronger desire of customers to do word of mouth.

The Islamic bank market segmentation is aimed at the Muslim community because its management system adheres to the Shariah principle where interest is usury and must be elevated because it is haram. For devout Muslims, avoiding usury means avoiding sins so that no matter how small usury must be abandoned, thus the cleaner the management of Islamic banks from the usury element will increasingly make customers satisfied. Likewise related to professional bank management in the sense that the bank never made a mistake, of course, it will provide a sense of satisfaction to the customer, thus the cleaner from the usury element and the more minimal making mistakes, then the more satisfied with, the more satisfied customer then, the greater intention to do positive word of mouth.

\section{CONCLUSION}

Customer satisfaction has a significant effect on word of mouth in Islamic Bank customers in Central Sulawesi Province so that if satisfaction increases, then the desire of sharia bank customers in Central Sulawesi to do WOM will also increase.

\section{REFERENCE}

1. Arpizal. (2018). Orientasi Pasar dan Keunggulan Bersaing: Studi Kasus Penjualan Komputer. Celebes Media Perkasa.

2. Harjanto, R., \& Mulyana, D. (2008). Komunikasi Getok Tular Pengantar Popularitas Merek.
Mediator: Jurnal Komunikasi, 9(2), 233-242. https://doi.org/10.29313/mediator.v9i2.1131

3. Glynn Mangold, W., Miller, F., \& Brockway, G. R. (1999). Word- of- mouth communication in the service marketplace. Journal of Services Marketing, 13(1), 73-89. https://doi.org/10.1108/08876049910256186

4. Kartajaya, H. (2007). Hermawan Kartajaya on Service. Mizan Pustaka.

5. Jayasankaraprasad, C., \& Kumar, P. V. V. (2012). Antecedents and consequences of customer satisfaction in food \& grocery retailing: An empirical analysis. Decision, 39(3), 101-140.

6. Wirtz, J., \& Chew, P. (2002). The effects of incentives deal proneness, satisfaction and tie strength on word- of- mouth behaviour. International Journal of Service Industry Management, 13(2), 141-162. https://doi.org/10.1108/09564230210425340

7. Sweeney, J. C., Soutar, G. N., \& Mazzarol, T. (2008). Factors influencing word of mouth effectiveness: Receiver perspectives. European Journal of Marketing, 42(3/4), 344-364. https://doi.org/10.1108/03090560810852977

8. Puspasari, A. (2014). Pengaruh Kualitas Produk terhadap Word of Mouth melalui Kepuasan Pelanggan. Jurnal Ilmu Manajemen, 2(4), 17371748.

9. Kotler, P., \& Armstrong, G. (2015). Principles of marketing (Sixteenth edition). Pearson.

10. Rusadi, Yuniar Ayu, \& Sujito. (2012). Analisis Pengaruh Kualitas Produk, Kualitas Pelayanan terhadap WOM Positif dengan Kepuasan Sebagai Variabel Intervening. Jurnal Ilmiah USM, 2(6), 3348.

11. Lovelock, Christoper, H, Wirtz., \& Jochen. (2011). Service marketing: People, technology, strategy (7th .ed ). Prentice - Hall.

12. Brown, Barry, Dacin., \& Gunst. (2005). Spreading the Word: Investigating Antecedents of Consumers Positive Word of Mouth Intentions and Behaviors in a retailing Context. Journal the Academy of Marketing Science, 33(2), 123-138.

13. Oliver., \& Swan. (1989). Consumer Perception on Interpersonal Equity and Satisfaction Transction: A Field Survey Approach. Joural of Marketing, 55(2), 21-35.

14. Hennig-Thurau, T., Gwinner, K. P., \& Gremler, D. D. (2016). Understanding Relationship Marketing Outcomes: An Integration of Relational Benefits and Relationship Quality. Journal of Service Research. https://doi.org/10.1177/1094670502004003006

15. Babin, B. J., Lee, Y., Kim, E., \& Griffin, M. (2005). Modeling consumer satisfaction and word- of- mouth: Restaurant patronage in Korea. Journal of Services Marketing, 19(3), 133-139. https://doi.org/10.1108/08876040510596803. 